
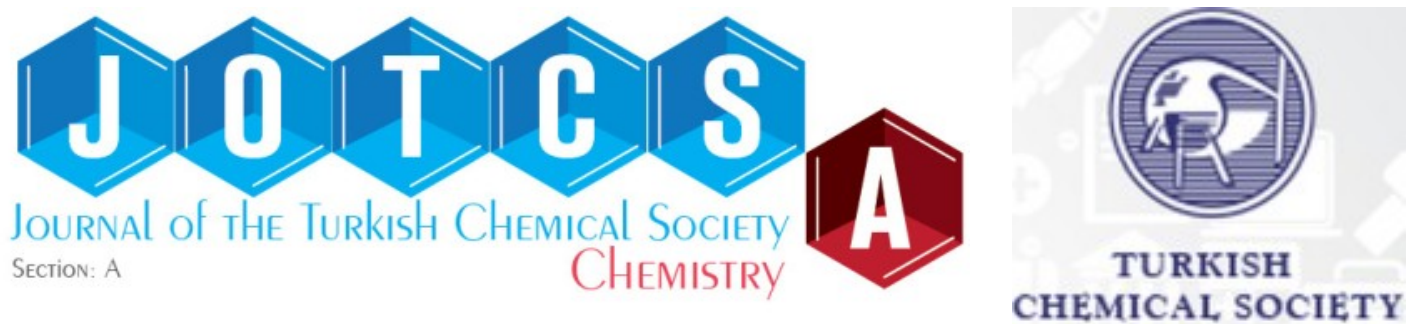

\title{
Low-cost Pencil-Graphite Multi-electrodes for Simultaneous Detection of Iron and Copper
}

\author{
Tugba OZER ${ }^{1 *} M$ \\ ${ }^{1}$ Yildiz Technical University, Department of Bioengineering, Faculty of Chemical and Metallurgical \\ Engineering, Istanbul, 34220, Turkey
}

\begin{abstract}
Herein, two novel ion-selective electrodes are reported for simultaneous potentiometric determination of $\mathrm{Fe}^{3+}$ and $\mathrm{Cu}^{2+}$ ions. The liquid polymeric membrane components were optimized and the resulting pencil graphite electrodes gave Nernstian slopes of $20.7 \mathrm{mV} /$ decade and $31.2 \mathrm{mV} /$ decade with lower detection of limit of $1 \times 10^{-6} \mathrm{~mol} \mathrm{~L}^{-1}$ and $2 \times 10^{-6} \mathrm{~mol} \mathrm{~L}^{-1}$, and wide $\mathrm{pH}$ range of 1.5-3.5 and 2.0-4.7 for $\mathrm{Fe}^{3+}$ and $\mathrm{Cu}^{2+}$ ions, respectively. The electrodes exhibited very fast response time $(<6 \mathrm{~s})$. In addition, the electrodes exhibited high selectivity for $\mathrm{Fe}^{3+}$ and $\mathrm{Cu}^{2+}$ ions against different cations, which were tested by matched potential method. The sensing platform using the optimized electrodes were integrated with the Internet of Things concept are suitable for simultaneous monitoring of $\mathrm{Fe}^{3+}$ and $\mathrm{Cu}^{2+}$ in real samples with high accuracy and precision.
\end{abstract}

Keywords: Potentiometric determination, ion selective electrode, copper, iron, internet of things, simultaneous determination.

Submitted: June 08, 2021. Accepted: November 16, 2021.

Cite this: Ozer T. Low-cost Pencil-Graphite Multi-electrodes for Simultaneous Detection of Iron and Copper. JOTCSA. 2022;9(1):1-12.

DOI: https://doi.org/10.18596/jotcsa.949831.

*Corresponding author. E-mail: tozer@yildiz.edu.tr.

\section{INTRODUCTION}

Heavy metals have been widely used in a variety of industries such as petrochemicals, metal processing, organic chemicals, pharmaceuticals, pesticides, and plastics (1). Due to the discharge of industrial effluents into natural waters, heavy metal ions adversely affect environment and human health (2). Among the heavy metals, $\mathrm{Fe}$ and $\mathrm{Cu}$ are the first and second most widely used industrial metals worldwide (3). $\mathrm{Fe}^{3+}$ plays a significant role in various metabolic processes including oxygen transport, enzyme catalysis, DNA and RNA synthesis, and hemoglobin synthesis (4). Although $\mathrm{Fe}^{3+}$ is necessary for living organisms at low concentrations, biological disorders such as Alzheimer's, Parkinson's, and Huntington's diseases and, renal failure are seen with uptake of $\mathrm{Fe}^{3+}$ at high concentrations (5). Similarly, excess copper causes anemia, bone disorders, diarrhea, infertility, hepatic and renal damages, and neurological disorders, thus, permissible limits of copper in ground water and drinking water are set as $3 \mathrm{mg} \mathrm{L}^{-1}$ and $2 \mathrm{mg} \mathrm{L}^{-1}$, respectively, by United States Environmental Protection Agency (EPA) and The World Health Organization (WHO) (6). In addition, the concentration of copper should not surpass 100$150 \mu \mathrm{g} \mathrm{dL}^{-1}\left(15.7-23.6 \mu \mathrm{mol} \mathrm{L}^{-1}\right)$ in human blood according to WHO. Thus, there is a need for a continuous and simultaneous sensing system for copper and iron to ensure water safety and public health.

There are many conventional techniques such as atomic absorption spectroscopy, atomic fluorescence spectrometry, chromatography, inductively coupled plasma mass spectrometry and ultraviolet-visible spectrophotometry for quantitative determination of heavy metals (7). Although these methods are highly sensitive and selective, they have several disadvantages such as labor-intensive and time-consuming experimental 
steps, the need of expensive and bulky instruments and specialized personnel (8). On the other hand, potentiometric method based on ion selective electrodes (ISEs) have been widely employed for quantitative and in-situ determination of target ion activity in aqueous samples owing to their advantages including simplicity, low-cost, rapid response, miniaturization, portability and low energy consumption (9). There have also been various reports of liquid membrane-based ISEs consisting of a plasticizer, a polymer (mostly polyvinyl chloride, PVC), an ionic additive, and an ionophore (10). Due to the semipermeable nature of PVC, it has been widely used for ISEs application (11). While the ionophore complexes with the metal ion of interest, the plasticizer enhances solubility and mobility of the ionophore in the membrane (12). In addition, lipophilic anionic additives such as sodium tetraphenyl borate and potassium tetrakis(4-chlorophenyl)borate (KTChPB) are utilized to enhance ISE sensitivity and selectivity while decreasing membrane resistance (11). Various ionophores such as calixarenes, crown ethers, macrocyclic polyethers, cyclic tetrapeptides, and thiophenes have been applied for the fabrication of $\mathrm{Cu}^{2+}$ and $\mathrm{Fe}^{3+}$ selective ISEs (13). Previously reported electrodes have drawbacks including higher limit of detection or interferences from other cations.

Porphyrins, which are a class of heterocyclic macromolecular compounds, can be utilized as ionophores for constructing cation-selective electrodes by grafting functional groups to the porphyrin ring (14). Recently, Chen et al. synthesized Gd-(5,10,15,20-tetrakis (4 carboxyphenyl) porphyrin to detect $\mathrm{Fe}^{3+}$ using colorimetric and fluorometric methods (15). Although low detection limits were achieved with the use of a polymer-based probe, their methods require bulky instruments an UV-visible spectrometer and fluorescence spectrometer, and they are not suitable for online monitoring of $\mathrm{Fe}^{3+}$. In addition, their assay showed a limited linear range of $10^{-4}$ and $0.5 \times 10^{-6} \mathrm{~mol} \mathrm{~L}^{-1}$. In our study, a new membrane consisting of $\mathrm{Fe}(\mathrm{III})$ octaethylporphyrin chloride $\left(\mathrm{C}_{36} \mathrm{H}_{44} \mathrm{ClFeN}_{4}\right)$ as an ionophore was used to develop low-cost and disposable ISEs for the first time. Selectivity and detection limits of the fabricated $\mathrm{Fe}^{3+}$ and $\mathrm{Cu}^{2+}$ selective electrodes were improved due to the optimization of membrane components including lipophilic additives and plasticizers. The electrodes had fast response time $(\leq 6 \mathrm{~s})$ and showed selectivity over various interfering cations. Also, the Internet of Things (IoT) concept was tested for onsite and simultaneous environmental monitoring of $\mathrm{Cu}^{2+}$ and $\mathrm{Fe}^{3+}$ using our developed ISEs. The sensing platform exploits the IoT approach to transmit the data to smartphones through a cloud service for the end-users. Furthermore, the characteristics of the electrodes were compared with the previous literature reports. The developed multianalyte sensor is advantageous over various methods due to their low-cost, fast response time, ease of fabrication, and applicability for the simultaneous quantification of iron and copper in water samples.

\section{EXPERIMENTAL SECTION}

\section{Reagents and Chemicals}

All chemicals and reagents were of analytical grade and utilized as received. Tetrahydrofuran (THF), KTChPB, Fe (III) octaethylporphyrin chloride, high molecular weight PVC and plasticizers, onitrophenyloctyl ether (NPOE), dioctylsebacate (DOS), dibutyl phthalate (DBP), dioctyl phthalate (DOP) were obtained from Fluka (Bucks, Switzerland). An 8B pencil graphite (2 mm, Koh-i Noor) was purchased from a local store and used without any pre-treatment. Ultrapure water $(\sim 18.2$ $\mathrm{M} \Omega \cdot \mathrm{cm}, 25^{\circ} \mathrm{C}$, ELGA LabWater, UK) was utilized to prepare all solutions of metal ions from their nitrate salts. Sodium hydroxide and nitric acid solutions with concentration between 0.1-1 $\mathrm{mol} \mathrm{L}^{-1}$ were used for adjusting solution $\mathrm{pH}$.

\section{Apparatus}

The potentiometric measurements were conducted using a portable multi-channel potentiostat (sensitivity: $\pm 0.1 \mathrm{mV}$ ) connected a smartphone through a WiFi module based on our previous study (16). A Ag/AgCl electrode (MF2052 model, BASi) was used as reference electrode (RE) during electrochemical measurements. Solution $\mathrm{pH}$ was tested with HI9126 (Hanna Instruments) portable $\mathrm{pH} / \mathrm{mV}$ meter. All measurements were carried out at room temperature $\left(25^{\circ} \mathrm{C}\right)$. Debye-Hückel equation was used to calculate the ion activity coefficients (17). The weight loss of the membrane was investigated as a function of temperature using a thermal gravimetric analyzer (TGA-DTA, TA Instruments, New Castle, DE, USA). Electrode holders were 3D printed (Formlab, USA). Modified electrodes and the $\mathrm{Ag} / \mathrm{AgCl}$ electrode were mounted onto the 3D-printed holder for electrochemical measurements.

\section{Procedure}

To prepare membrane cocktails, the ionophore, KTChPB and DOS, DBP, DOP or NPOE plasticizers were dissolved in THF (18). The cocktail solution was let evaporate at room temperature. $20 \mu \mathrm{L}$ of membrane cocktail was dropped on the surface of each pencil graphite electrode and left at ambient temperature for $2 \mathrm{~h}$ to allow the THF to evaporate. Finally, the electrodes were equilibrated into a $10^{-2}$ $\mathrm{mol} \mathrm{L}^{-1}$ solution of each ion for $12 \mathrm{~h}$ before use. The ion-selective electrodes along with $\mathrm{Ag} / \mathrm{AgCl}$ reference electrode were assembled using a fabricated 3D-printed holder. The potentiometric sensors and the reference electrode connected to the multi-channel potentiostat were dipped into 10 

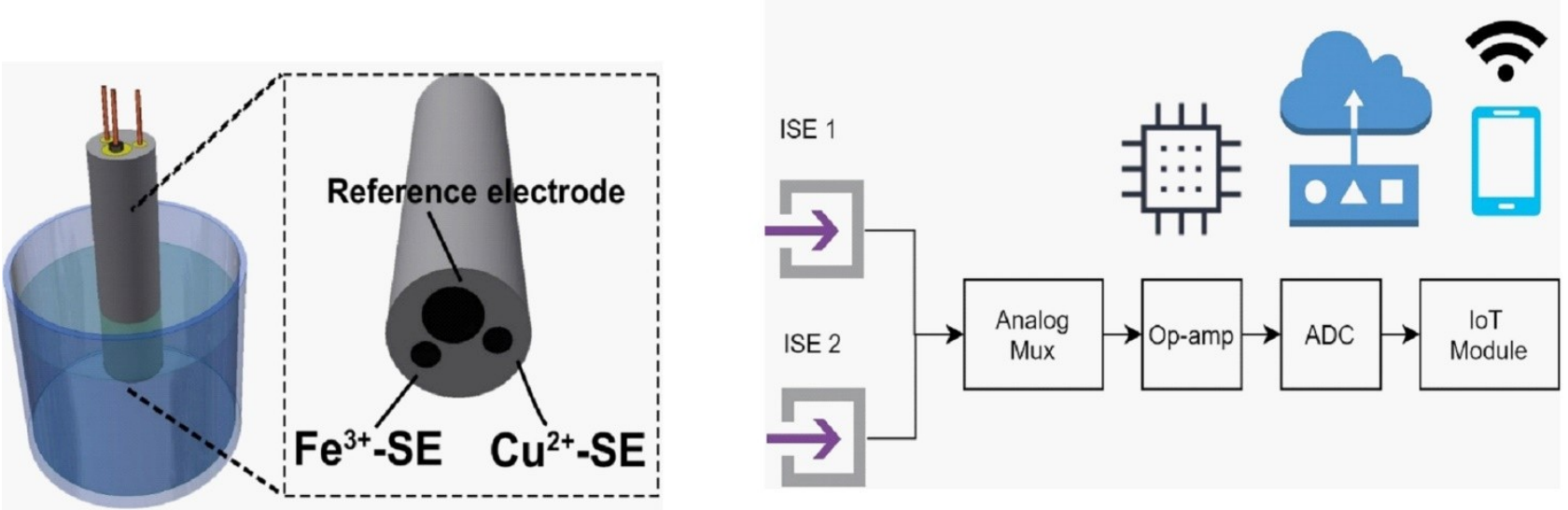

Figure 1: Schematic representation of the electrochemical measurement cell and diagram of the IoT data acquisition process.

\section{RESULTS AND DISCUSSION}

To investigate the potentiometric behavior of the electrodes towards different cations, the developed electrodes were submerged into nitrate/chloride solutions of corresponding cations, which were adjusted to $\mathrm{pH}=3$, for overnight. The slopes of the corresponding potential values versus logarithmic activity of ion plots exhibited much lower than the Nernstian slopes excepting $\mathrm{Fe}^{3+}$ and $\mathrm{Cu}^{2+}$ ions, respectively (Figure $2 a$ and $2 b$ ). Therefore, Fe(III) octaethylporphyrin chloride was selected for preparation of $\mathrm{Fe}^{3+}$ and $\mathrm{Cu}^{2+}$-selective membranes.

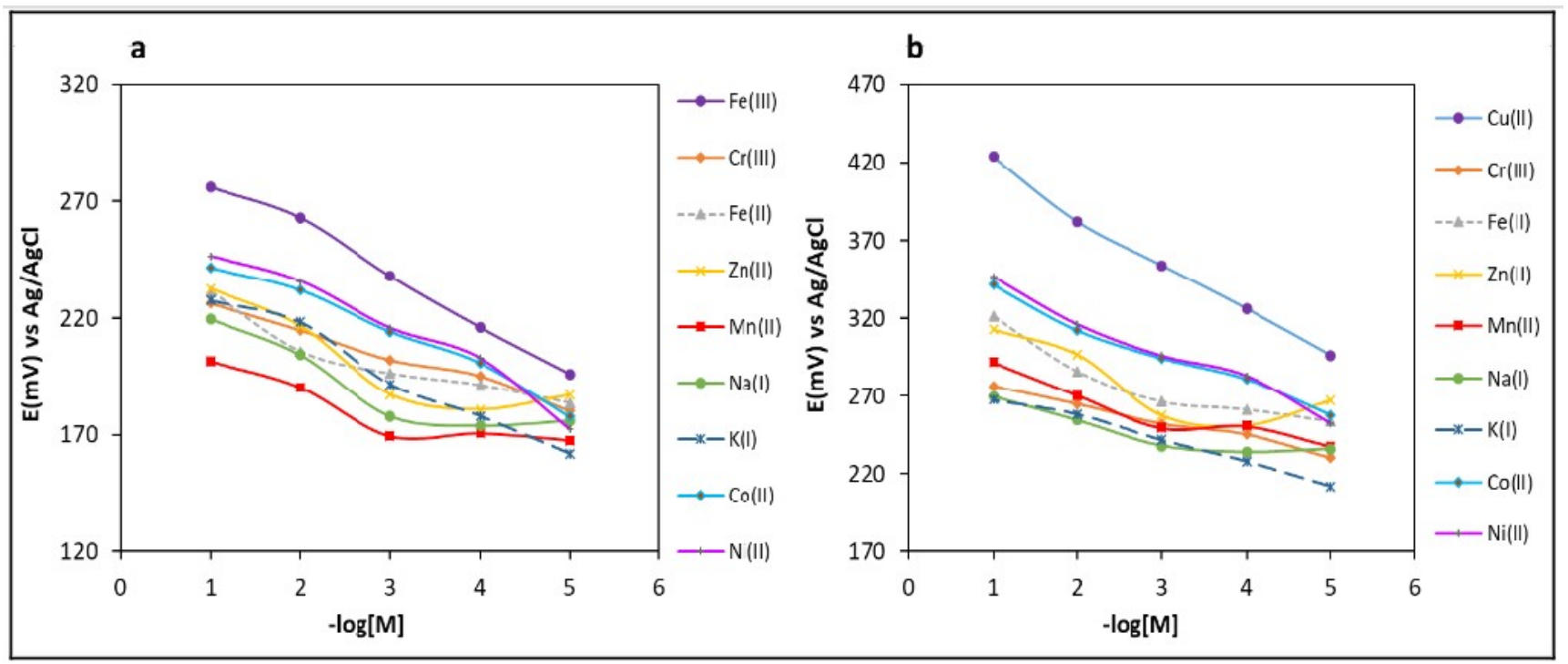

Figure 2: The EMF signals of (a) $\mathrm{Fe}^{3+}$-selective electrode (b) $\mathrm{Cu}^{2+}$ - selective electrode towards different ions.

\section{Optimization of the Proposed Electrodes}

The properties and component amounts for the membrane have significant effect on the performance of an ISE due to rapid interfacial reaction of a target metal ion at the membraneaqueous interface. After various compositions of the membrane were prepared, their potentiometric responses were recorded as a function of primary ions concentration. Ion-selective membrane was prepared using (by weight) $0.3 \%$ KTChPB, $1 \%$ ionophore, $65.8 \%$ plasticizer, and $32.9 \%$ PVC in
THF. DOS and NPOE were used as plasticizers for preparation of iron-selective and copper-selective membrane, respectively. $200 \mathrm{mg}$ of the membrane components were mixed in $2 \mathrm{~mL}$ of THF in a glass vial and homogenized using an ultrasonicator for 5 min. The optimized membrane composition was used to prepare the electrodes as presented in the experimental section. Then, a Mututoya digital micrometer (Japan) was used to measure the thickness of the membrane and was found to be $0.20 \pm 0.09 \mathrm{~mm}$. 
The potential response values of the electrodes were recorded in different activities of $\mathrm{Fe}^{3+}$ and $\mathrm{Cu}^{2+}$ solutions and a calibration curve was plotted for each ion (Figure $3 a$ and $3 b$ ). Nernstian slope, which is the function of different activity of analytes, is shown as the slope of the calibration curve.

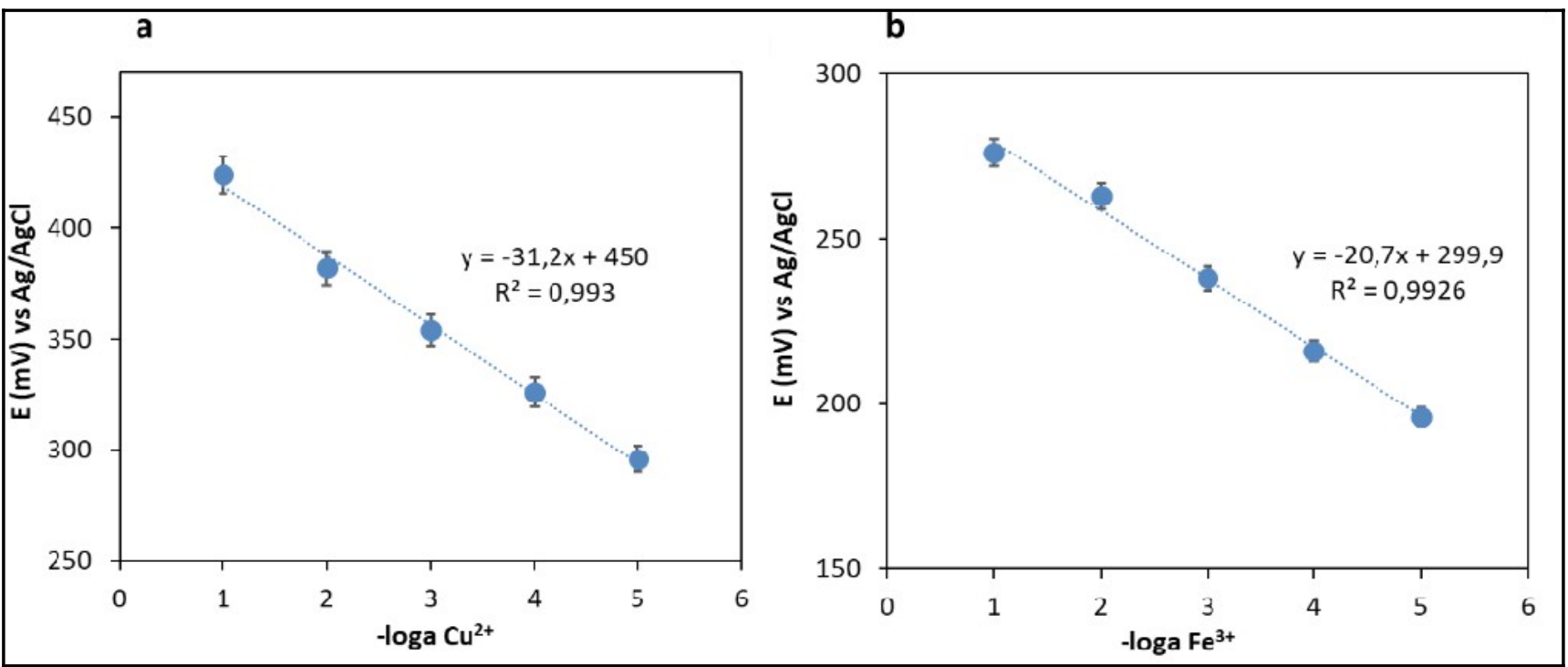

Figure 3: Calibration curve of the solid-contact (a) $\mathrm{Cu}^{2+}$ ISE and (b) $\mathrm{Fe}^{3+}$ ISE. Each error bar represents one standard deviation for three measurements.

For $\mathrm{Fe}^{3+}$-selective electrode, the membrane composition (M5) including $1 \%$ ionophore, $65.8 \%$ DOS, $0.3 \%$ KTChPB and $32.9 \%$ PVC showed a slope of $20.7 \mathrm{mV} /$ decade, which shows the ideal Nernstian slope for trivalent ions, and a limit of detection (LOD) of $1 \times 10^{-6} \mathrm{~mol} \mathrm{~L}^{-1}$ calculated from intersection of two slope lines. The relationship between the potential response of the $\mathrm{Cu}^{2+}$-selective electrode consisting of membrane $\mathrm{M7}$ and logarithm of ion activity was linear from $1 \times 10^{-5} \mathrm{~mol} \mathrm{~L}^{-1}$ to $1 \times 10^{-1}$ mol $\mathrm{L}^{-1}$ with a slope of $31.2 \mathrm{mV} /$ decade showing Nernstian response and a LOD of $2 \times 10^{-6} \mathrm{~mol} \mathrm{~L}^{-1}$. According to the results presented in Table 1 , it was observed that the presence of KTpCIPB in the membrane enhanced the calibration curve slope.
The Donnan exclusion was improved by increased amount of KTpCIPB to $30 \mathrm{~mol} \%$ (19). Plasticizer NPOE is suitable for ISEs for detection of divalent ions (11). Moreover, a polymeric membrane including more polar plasticizer, $\operatorname{NPOE}(\varepsilon=24)$, exhibited an increased potential response slope and a lower detection limit for $\mathrm{Cu}^{2+}$ compared to the membrane consisting of PVC-DOS $(\varepsilon=4.8)$. Similarly, better sensitivity and enhanced detection limit were obtained using PVC-DOS membrane for $\mathrm{Fe}^{3+}$ detection compared to membranes containing other types of plasticizers. According to these results, it was observed that the composition of ion selective membrane has significant impact on LOD values and sensitivity of the electrodes.

Table 1: Composition and characterization of $\mathrm{Cu}^{2+}$ ISE and $\mathrm{Fe}^{3+}$ ISE having PVC:Plasticizer (1:2) Membrane consisting of 1 wt \% ionophore and KTChPB ( $\mathrm{mol} \%$ )

\begin{tabular}{|c|c|c|c|c|c|c|}
\hline \multirow[b]{2}{*}{ Electrode } & \multirow[b]{2}{*}{$\begin{array}{l}\text { KTChPB } \\
(\mathrm{mol} \%)\end{array}$} & \multirow[b]{2}{*}{ Plasticizer } & \multicolumn{2}{|c|}{$\mathrm{Cu}^{2+}$ ISE } & \multicolumn{2}{|c|}{$\mathrm{Fe}^{3+}$ ISE } \\
\hline & & & $\begin{array}{c}\text { Slope } \\
(\mathrm{mV} / \mathrm{dec})\end{array}$ & $\begin{array}{c}\text { Detection } \\
\text { limit } \\
\left(\mathrm{mol} \mathrm{L}^{-1}\right)\end{array}$ & $\begin{array}{c}\text { Slope } \\
(\mathrm{mV} / \mathrm{dec})\end{array}$ & $\begin{array}{c}\text { Detection } \\
\text { limit } \\
\left(\mathrm{mol} \mathrm{L} \mathbf{L}^{-1}\right)\end{array}$ \\
\hline M1 & 10 & NPOE & 27.3 & $7 \times 10^{-6}$ & 17.5 & $6 \times 10^{-4}$ \\
\hline M2 & 50 & NPOE & 35.4 & $1 \times 10^{-6}$ & 18.6 & $5 \times 10^{-4}$ \\
\hline M3 & 10 & DOS & 23.1 & $3 \times 10^{-5}$ & 18.9 & $3.2 \times 10^{-5}$ \\
\hline M4 & 50 & DOS & 27.3 & $5 \times 10^{-5}$ & 18.5 & $1 \times 10^{-5}$ \\
\hline M5 & 30 & DOS & 27.7 & $5 \times 10^{-5}$ & 20.1 & $1 \times 10^{-6}$ \\
\hline M6 & - & DOS & - & - & 15.2 & $5.4 \times 10^{-4}$ \\
\hline M7 & 30 & NPOE & 31.2 & $2 \times 10^{-6}$ & 18.7 & $6.5 \times 10^{-5}$ \\
\hline M8 & 30 & DOP & 26.5 & $1 \times 10^{-4}$ & 18.4 & $2.3 \times 10^{-4}$ \\
\hline M9 & 30 & DBP & 25.3 & $1 \times 10^{-4}$ & 18.2 & $5 \times 10^{-4}$ \\
\hline M10 & - & NPOE & 20.6 & $6.2 \times 10^{-4}$ & - & - \\
\hline
\end{tabular}

\section{Effect of pH}

The $\mathrm{pH}$ effect on the potentiometric response of the electrodes was investigated at a fixed concentration 
$\left(1 \times 10^{-3} \mathrm{~mol} \mathrm{~L}^{-1}\right)$ in the $\mathrm{pH}$ range between 1.0 and 8.0. The potential values are plotted in Figure $4 a$ and $4 \mathrm{~b}$. It was observed that the potential response of the electrodes were constant at $\mathrm{pH}$ values in the range of 1.5-3.5 and 2.0-4.7, which could be considered as the working $\mathrm{pH}$ range of iron- and copper-selective electrodes, respectively. Due to the binding of $\mathrm{H}^{+} / \mathrm{OH}^{-}$, the potential changes might be observed with high acidity or alkalinity of the solution. Potential responses were not independent at $\mathrm{pH}$ lower than 1.5 and $\mathrm{pH}$ higher than 3.5 because of protonation of the ionophore and formation of ferric hydroxide in the solution, respectively. Similarly, change in equilibrium potential below 4.7 and above 2.0 could be due to hydrolysis of $\mathrm{Cu}^{2+}$ resulting in formation of more $\mathrm{H}^{+}$ ions competing with $\mathrm{Cu}^{2+}(20)$.
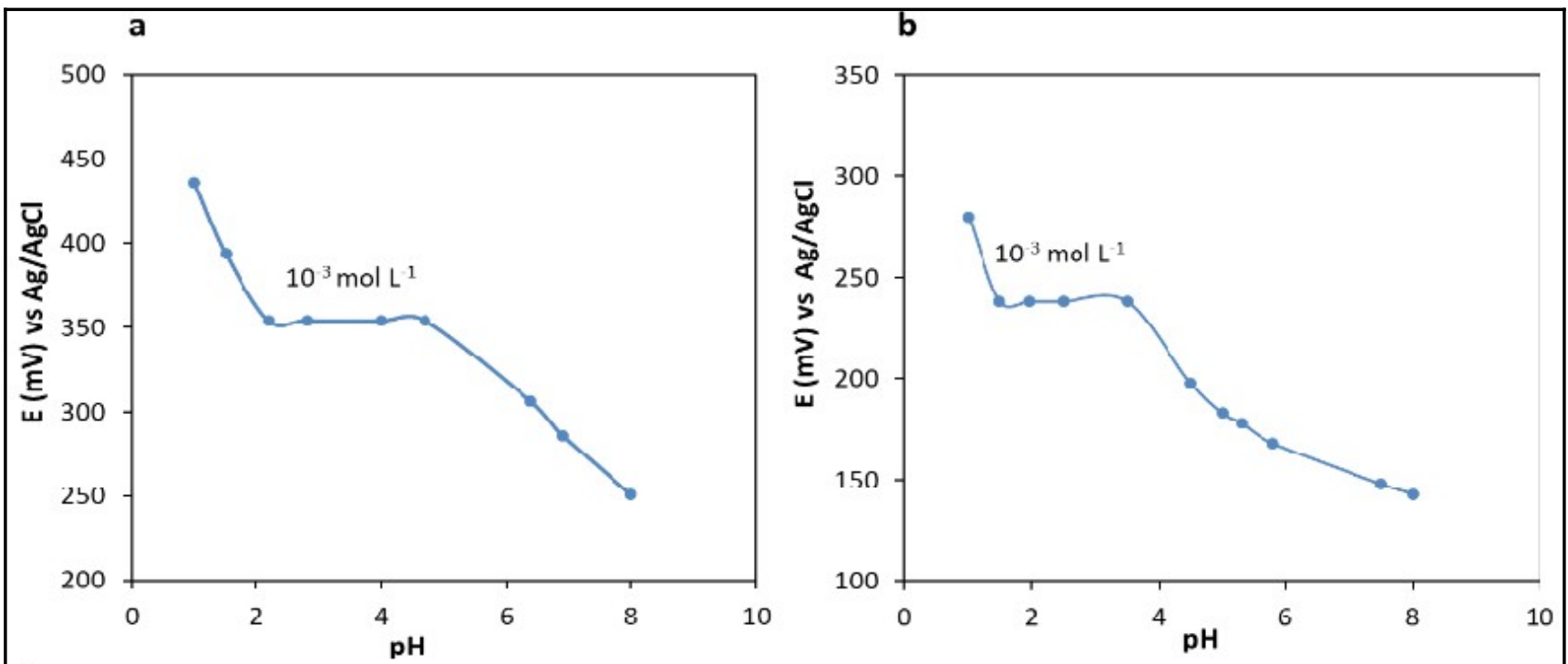

Figure 4: $\mathrm{pH}$ effect of the solutions to the EMF signals of (a) $\mathrm{Cu}^{2+}$ ISE and (b) $\mathrm{Fe}^{3+}$ ISE.

Response Time, Repeatability, Reproducibility, and Stability of the Electrodes

Electrodes response times were recorded with the time required to achieve $95 \%$ of final equilibrium electromotive force (EMF) signal after successive immersion of the test solutions within the concentration from $1.0 \times 10^{-6} \mathrm{~mol} \mathrm{~L}^{-1}$ to $1.0 \times 10^{-2} \mathrm{~mol}$ $\mathrm{L}^{-1}$. The electrode response times were obtained as $6 \mathrm{~s}$ and $4 \mathrm{~s}$ for detection of $\mathrm{Fe}^{3+}$ and $\mathrm{Cu}^{2+}$, respectively (Figure $5 a$ and $5 b$ ), which is suitable for in-situ detection. The short response time of the electrodes was the result of the fast exchange kinetics between association and dissociation of ions with the porphyrin derivative ionophore at the membrane surface. It is necessary to obtain consistent performance after utilization of the electrodes repeatedly for real-time monitoring water. Thus, the repeatability and reproducibility tests $(n=5)$ of the electrodes were performed in $1.0 \times 10^{-3} \mathrm{~mol} \mathrm{~L}^{-1} \mathrm{Fe}^{3+}$ and $\mathrm{Cu}^{2+}$ solutions. While RSDs (relative standard deviations) have been calculated as $2.4 \%$ and $2.7 \%$ for repeatability of $\mathrm{Fe}^{3+}$ and $\mathrm{Cu}^{2+}$ selective electrodes, respectively, RSDs were found as $3.2 \%$ and $3.0 \%$ for reproducibility of the electrodes. Moreover, longterm stability of the electrodes were investigated using same electrodes during eight weeks and the calibration plot slopes were decreased by $5 \%$ and $7 \%$ for $\mathrm{Fe}^{3+}$ and $\mathrm{Cu}^{2+}$ selective electrodes, respectively. Since the change were not significant, they could be used during this period. 


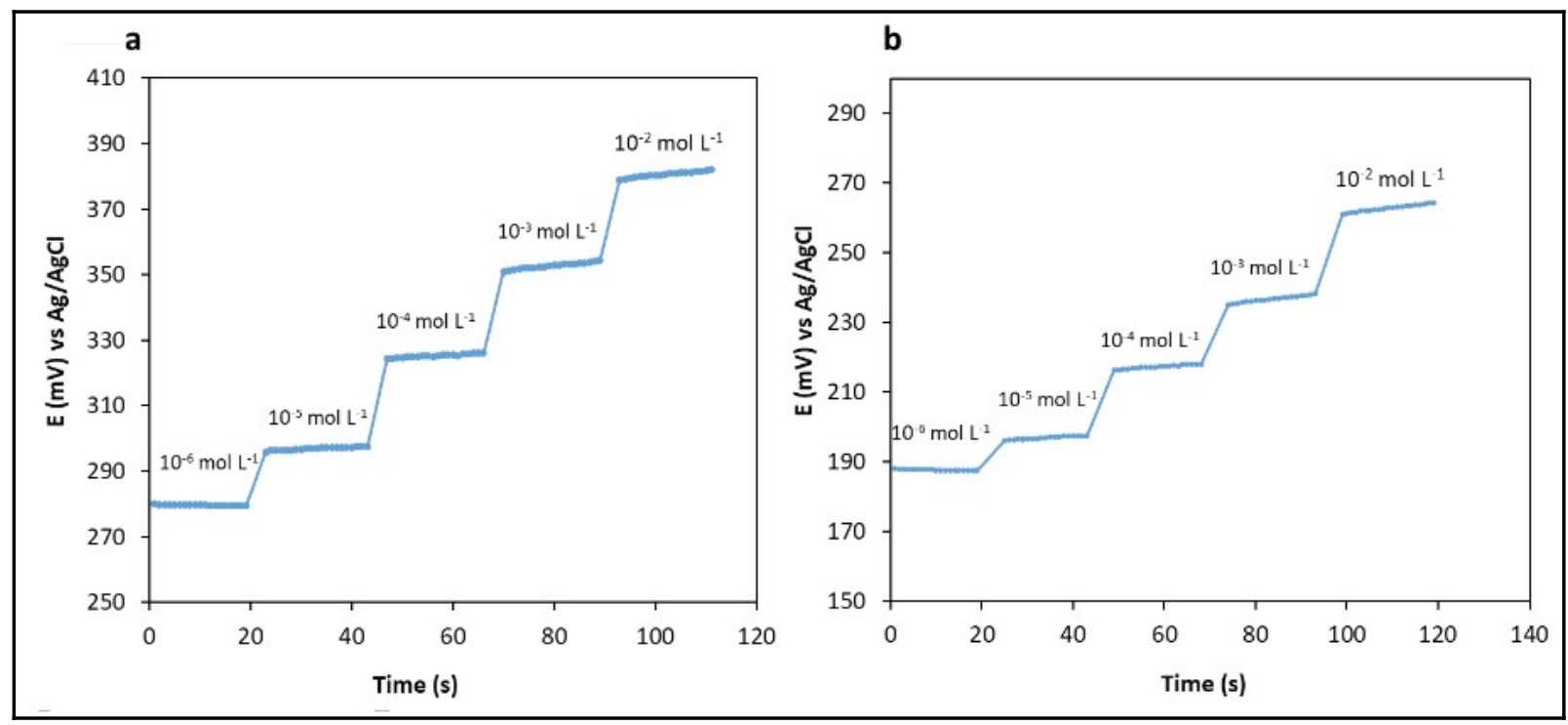

Figure 5: Response time of (a) $\mathrm{Cu}^{2+} \mathrm{ISE}$ and (b) $\mathrm{Fe}^{3+}$ ISE for step change in concentrations.

\section{Interference Study}

The interference effect of other cations to the response of developed electrodes were investigated since selectivity coefficient represent the ability of the electrode to discriminate the target ion in the presence of interfering ions. For determination of the selectivity coefficients, the matched potential method (MPM) was used (21). The potential response $(\Delta E)$ value was recorded while the activity of primary ions changed from $\mathrm{a}_{\mathrm{A}}=5 \times 10^{-4} \mathrm{~mol} \mathrm{~L}^{-1}$ to $a_{A}^{\prime}=5 \times 10^{-3} \mathrm{~mol} \mathrm{~L}^{-1}$. Until the same $\Delta \mathrm{E}$ was obtained, $0.1 \mathrm{~mol} \mathrm{~L}^{-1}$ solution of the interfering ion (ав) was added to primary ion solution. The values of the sensor selectivity coefficient are evaluated using the equation (Equation 1) and presented in Table 2.

$$
K_{A, B}=\left(a^{\prime}{ }_{A}-a_{A}\right) / a_{B}
$$

It can be seen in Table 2 that interferences with metal ions including $\mathrm{Na}^{+}, \mathrm{K}^{+}, \mathrm{Mn}^{2+}, \mathrm{Zn}^{2+}, \mathrm{Ni}^{2+}, \mathrm{CO}^{2+}$ $\mathrm{Fe}^{2+}$, and $\mathrm{Cr}^{3+}$ are negligible for the developed electrodes since the selectivity coefficient values were lower than 1 (22).

Table 2: Potentiometric selectivity coefficients of the developed ISEs.

\begin{tabular}{|c|c|c|}
\hline & $\log K_{i, j}{ }^{a}$ & $\log K_{i, j}{ }^{a}$ \\
\hline Ion & $\mathrm{Cu}^{2+} \mathrm{ISE}$ & $\mathrm{Fe}^{3+}$ ISE \\
\hline $\mathrm{Na}^{+}$ & -3.6 & -4.3 \\
\hline $\mathrm{K}^{+}$ & -3.8 & -4.4 \\
\hline $\mathrm{Mn}^{2+}$ & -2.8 & -2.4 \\
\hline $\mathrm{Zn}^{2+}$ & -2.5 & -2.4 \\
\hline $\mathrm{Fe}^{2+}$ & -3.0 & -3.2 \\
\hline $\mathrm{Cu}^{2+}$ & - & -3.5 \\
\hline $\mathrm{Ni}^{2+}$ & -2.8 & -2.9 \\
\hline $\mathrm{Co}^{2+}$ & -2.7 & -2.2 \\
\hline $\mathrm{Fe}^{3+}$ & -3.5 & - \\
\hline $\mathrm{Cr}^{3+}$ & -4.5 & -3.1 \\
\hline
\end{tabular}

${ }^{a}$ Average value obtained from the three corresponding pairs of concentrations of $\mathrm{Cu}^{2+}$, $\mathrm{Fe}^{3+}$ and the respective interfering cation.

\section{Thermogravimetric Analysis}

The results of the thermal analysis of the PVC/ionophore/NPOE and PVC/ionophore/DOS membranes are presented in Figure $6 a$ and Figure $6 \mathrm{~b}$, respectively. Weight loss of the membranes started to be seen at 293 and $295{ }^{\circ} \mathrm{C}$, respectively. At temperatures which the initial mass loss was observed, the loss of mass was equal to $11.68 \%$ and $14.59 \%$ for the slow decomposition of the material in the TGA measurement. The inorganic contents of the component underwent degradation based on the curve which was at $455^{\circ} \mathrm{C}$ onwards. A single large peak was found at $\sim 295^{\circ} \mathrm{C}$, which indicate the exothermic reaction in the composite in the DTGA curve (Figure 6b). The thermal decomposition of the polymeric membrane showed the similar general weight loss pattern to the reported values of $200-350{ }^{\circ} \mathrm{C}$ and $450-600{ }^{\circ} \mathrm{C}$ (23). These results include that the membranes are thermally stable and can be used at higher temperatures. 


\section{Analytical Applications}

$10 \mathrm{~mL}$ aliquot samples of tap water were spiked with standard $\mathrm{Fe}^{3+}$ or $\mathrm{Cu}^{2+}$ solutions at $\mathrm{pH}=3$. For each increment, the concentration of $\mathrm{Fe}^{3+}$ or $\mathrm{Cu}^{2+}$ sample solution was calculated using the change in potential responses $(\mathrm{mV})$. Next, the environmental water sample was used for application of the developed sensing platform integrated with WiFi to an IoT based web server (ThingSpeak.com) and the real-time data was validated with standard addition method and exhibited in Table 3. In addition, the electrodes were utilized to determine $\mathrm{Fe}^{3+}$ and $\mathrm{Cu}^{2+}$ ion concentration in spiked tap water with standard addition method (Table 3). There were no significant differences between the determination results of the developed electrodes. Since the results obtained using $\mathrm{Fe}^{3+}$-ISE and $\mathrm{Cu}^{2+}$-ISE are in good agreement with added values, the proposed methodology has great promise for accurate and simultaneous quantification of $\mathrm{Fe}^{3+}$ and $\mathrm{Cu}^{2+}$ ions in water samples.

a
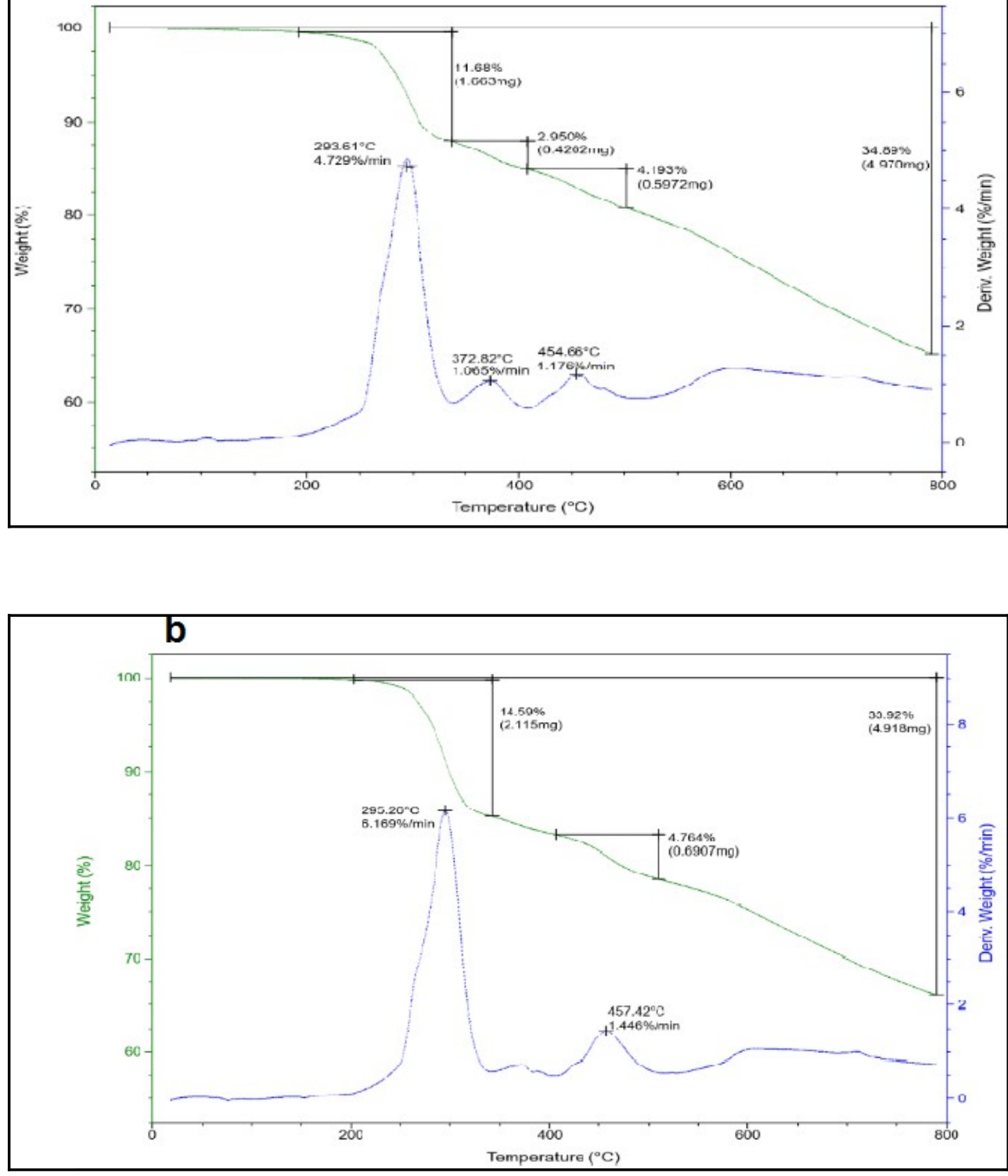

Figure 6: TGA spectra of (a) PVC/ionophore/NPOE and (b) PVC/ionophore/DOS up to $800^{\circ} \mathrm{C}$ in nitrogen atmosphere. 
Table 3: The results for the simultaneous detection of $\mathrm{Cu}^{2+}$ and $\mathrm{Fe}^{3+}$ in water samples using developed

\begin{tabular}{|c|c|c|c|c|c|}
\hline Sample & $\begin{array}{c}\text { Added } \\
(\mu \mathrm{mol} \\
\left.\mathbf{L}^{-1}\right)\end{array}$ & $\begin{array}{c}\mathrm{Cu}^{2+} \mathrm{ISE} \\
(\text { measured } \\
\text { value, } \mu \mathrm{mol} \mathrm{L^{- }} \\
\left.{ }_{1}\right)\end{array}$ & $\begin{array}{c}\text { Recovery } \\
(\%)\end{array}$ & $\begin{array}{c}\mathrm{Fe}^{3+} \mathrm{ISE} \\
\text { (measured } \\
\text { value, } \\
\text { pmol L-1) }\end{array}$ & $\begin{array}{c}\text { Recovery } \\
(\%)\end{array}$ \\
\hline Tap water 1 & 10 & $10.06 \pm 0.09$ & 100.6 & $10.08 \pm 0.09$ & 100.8 \\
\hline Tap water 2 & 20 & $20.3 \pm 0.1$ & 101.5 & $19.9 \pm 0.1$ & 99.5 \\
\hline Tap water 2 & 50 & $49.3 \pm 0.1$ & 98.6 & $50.1 \pm 0.2$ & 100.2 \\
\hline $\begin{array}{c}\text { Environmental } \\
\text { water }\end{array}$ & 50 & $49.40 \pm 0.1$ & 98.8 & $49.8 \pm 0.2$ & 99.6 \\
\hline
\end{tabular}

Comparison of the $\mathrm{Fe}^{3+}$ and $\mathrm{Cu}^{2+}$ Ion-Selective Electrodes with other ISEs

The response characteristics of other $\mathrm{Fe}^{3+}$ and $\mathrm{Cu}^{2+}$ ISEs in the literature ions are compared with the proposed electrodes in Tables 4 and 5 . Consequently, the developed electrodes for detection of $\mathrm{Fe}^{3+}$ and $\mathrm{Cu}^{2+}$ ions show better LOD and wider linear concentration ranges compared to the most of previous works.

\section{CONCLUSION}

It is important to detect metal ions in environmental samples to protect human health and ecosystem. The routine analysis of iron and copper are typically performed using bulky instruments such as atomic absorption spectroscopy, inductively coupled plasma-optical emission spectrophotometry, inductively coupled plasma mass spectrometry, and spectrophotometry, which require trained personnel to operate, large amount of samples/reagents and transportation of samples to the laboratory. On the other hand, the electrochemical sensors integrated with IoT provide autonomous decisions along with the obtained data, allowing rapid response time of sensing platforms in a user-friendly manner. The utilization of smart technology is crucial for in-field applications of environmental samples.

In this study, a new low-cost IoT-based sensing platform using disposable pencil graphite electrodes is developed for simultaneous and sensitive detection of $\mathrm{Fe}^{3+}$ and $\mathrm{Cu}^{2+}$ ions. Fe (III) octaethylporphyrin chloride was used as ionophore for the polymeric membrane $\mathrm{Fe}^{3+}$-ISE and $\mathrm{Cu}^{2+}$-ISE for the first time. The membrane components were optimized and resulted in improved Nernstian responses towards $\mathrm{Fe}^{3+}$ and $\mathrm{Cu}^{2+}$, slope of 20.7 $\mathrm{mV} /$ decade and $31.2 \mathrm{mV} /$ decade with LOD of $1 \times 10^{-6}$ mol L-1 and $2 \times 10^{-6} \mathrm{~mol} \mathrm{~L}^{-1}$, respectively. The results demonstrate that the fabricated ISEs are able to be employed in a $\mathrm{pH}$ range of 1.5-3.5 and 2.0-4.7 for $\mathrm{Fe}^{3+}$ and $\mathrm{Cu}^{2+}$ ions respectively, with rapid response, good reversibility, and a long-time stability. The electrodes had no interference in the presence of common ions. High thermal membrane stability was observed in TGA studies. Furthermore, the ISEs were successfully used to detect $\mathrm{Fe}^{3+}$ and $\mathrm{Cu}^{2+}$ in spiked and real water samples with good recoveries. The proposed system is suitable for realtime monitoring of $\mathrm{Fe}^{3+}$ and $\mathrm{Cu}^{2+}$ ions in water. 
Table 4: The developed $\mathrm{Fe}^{3+}$-selective electrode compared to other electrodes in the literature.

\begin{tabular}{|c|c|c|c|c|c|}
\hline Ionophore & Linear Range $\left(\mathrm{mol} \mathrm{L}^{-1}\right)$ & LOD $\left(\mathrm{mol} \mathrm{L}^{-1}\right)$ & $\begin{array}{l}\text { Response time } \\
\text { (s) }\end{array}$ & pH range & Ref. \\
\hline $\begin{array}{l}\text { 1) Phosphorylated Calix-6-Arene } \\
\text { Derivative }\end{array}$ & $\begin{array}{l}1.0 \times 10^{-2} \\
1.0 \times 10^{-4}\end{array}$ & $1.0 \times 10^{-5}$ & 5 & $4.0-7.0$ & $(24)$ \\
\hline 2) norfloxacin & $1.0 \times 10^{-1}-1.0 \times 10^{-5}$ & $5.0 \times 10^{-6}$ & 10 & $3.0-8.0$ & (25) \\
\hline 3) morin-Fe ${ }^{2+}$ schiff-base complex & $1.0 \times 10^{-1}-1.0 \times 10^{-6}$ & $4.5 \times 10^{-7}$ & $<10$ & $5.0-10.0$ & $(26)$ \\
\hline 4) Iron (II) Phthalocyanines & $1.0 \times 10^{-1}-1.0 \times 10^{-6}$ & $1.8 \times 10^{-7}$ & $<7$ & $3.5-5.7$ & $(18)$ \\
\hline $\begin{array}{l}\text { 5) Iron(III) phosphate and silver } \\
\text { sulfide }\end{array}$ & $1.0 \times 10^{-2}-3.97 \times 10^{-5}$ & $2.41 \times 10^{-5}$ & Not tested & 1 & $(27)$ \\
\hline $\begin{array}{l}\text { 6) Fe(III) octaethylporphyrin } \\
\text { chloride }\end{array}$ & $1.0 \times 10^{-1}-1.0 \times 10^{-5}$ & $1 \times 10^{-6}$ & 6 & $1.5-3.5$ & This work \\
\hline
\end{tabular}

Table 5. The developed $\mathrm{Cu}^{2+}$-selective electrode compared to other electrodes in the literature.

\begin{tabular}{|c|c|c|c|c|c|}
\hline Ionophore & Linear Range $\left(\mathrm{mol} \mathrm{L}^{-1}\right)$ & LOD $\left(\mathrm{mol} \mathrm{L}^{-1}\right)$ & $\begin{array}{l}\text { Response time } \\
\text { (s) }\end{array}$ & pH range & Ref. \\
\hline 1) 1-ethyl-3-methyl imidazolium chloride & $1.0 \times 10^{-1}-1.0 \times 10^{-7}$ & $3.2 \times 10^{-8}$ & $5-10$ & $2.5-6.0$ & $(28)$ \\
\hline $\begin{array}{l}\text { 2) Rhodamine } 6 \mathrm{~g} \\
\text { 3) phenanthroline-tetraphenyl borate } \\
\text { 4) thiohydrazone and thiosemicarbazone } \\
\text { ligands }\end{array}$ & $\begin{array}{l}1.0 \times 10^{-2}-4.3 \times 10^{-7} \\
1.0 \times 10^{-2}-1.0 \times 10^{-6} \\
1.0 \times 10^{-2}-1.0 \times 10^{-5}\end{array}$ & $\begin{array}{l}4.3 \times 10^{-7} \\
1.0 \times 10^{-6} \\
2.5 \times 10^{-6}\end{array}$ & $\begin{array}{l}15 \\
8 \\
2-18\end{array}$ & $\begin{array}{l}4.0-7.5 \\
3.8-5 \\
-\end{array}$ & $\begin{array}{l}(3) \\
(29) \\
(30)\end{array}$ \\
\hline $\begin{array}{l}\text { 5) cyclic tetrapeptide derivatives } \\
\text { 6) Fe (III) octaethylporphyrin chloride }\end{array}$ & $\begin{array}{l}1.0 \times 10^{-2}-3.1 .0 \times 10^{-6} \\
1.0 \times 10^{-1}-1.0 \times 10^{-5}\end{array}$ & $\begin{array}{l}2.1 \times 10^{-6} \\
2 \times 10^{-6}\end{array}$ & $\begin{array}{l}<15 \\
4\end{array}$ & $\begin{array}{l}4.5-7 \\
2.0-4.7\end{array}$ & $\begin{array}{l}(31) \\
\text { This work }\end{array}$ \\
\hline
\end{tabular}




\section{CONFLICT OF INTEREST}

The author declares that they have no known competing financial interests or personal relationships that could have appeared to influence the work reported in this paper.

\section{ACKNOWLEDGEMENTS}

This work was supported by Yildiz Technical University Scientific Research Projects Coordination Unit under project number FBA-2021-4389. I would like to thank Prof. Dr. Charles S. Henry for editing English language throughout the manuscript.

\section{REFERENCES}

1. Ghasemi Z, Mohammadi A. Sensitive and selective colorimetric detection of $\mathrm{Cu}$ (II) in water samples by thiazolylazopyrimidine-functionalized TiO2 nanoparticles. Spectrochimica Acta Part A: Molecular and Biomolecular Spectroscopy. 2020 Oct;239:118554. <DOI $>$.

2. Kaur I, Sharma M, Kaur S, Kaur A. Ultra-sensitive electrochemical sensors based on self-assembled chelating dithiol on gold electrode for trace level detection of copper(II) ions. Sensors and Actuators B: Chemical. 2020 Jun;312:127935. <DOI>.

3. Paul A, Nair RR, Chatterjee PB, Srivastava DN. Fabrication of a $\mathrm{Cu}(\mathrm{II})$-Selective Electrode in the Polyvinyl Chloride Matrix Utilizing Mechanochemically Synthesized Rhodamine $6 \mathrm{~g}$ as an Ionophore. ACS Omega. 2018 Nov 30;3(11):16230-7. <DOI $>$.

4. Tang S, Chang Y, Shen W, Lee HK. Selective extraction by dissolvable (nitriloacetic acid-nickel)layered double hydroxide coupled with reaction with potassium thiocyanate for sensitive detection of iron(III). Talanta. 2016 Jul;154:416-22. <DOI>.

5. Zhao Y, Ouyang H, Feng S, Luo Y, Shi Q, Zhu C, et al. Rapid and selective detection of Fe (III) by using a smartphone-based device as a portable detector and hydroxyl functionalized metal-organic frameworks as the fluorescence probe. Analytica Chimica Acta. 2019 Oct;1077:160-6. <DOI>.

6. Di Masi S, Pennetta A, Guerreiro A, Canfarotta F, De Benedetto GE, Malitesta $C$. Sensor based on electrosynthesised imprinted polymeric film for rapid and trace detection of copper(II) ions. Sensors and Actuators B: Chemical. 2020 Mar;307:127648. $<$ DOI $>$.

7. Akhond M, Absalan G, Pourshamsi T, Ramezani AM. Gas-assisted dispersive liquid-phase microextraction using ionic liquid as extracting solvent for spectrophotometric speciation of copper. Talanta. 2016 Jul;154:461-6. <DOI>.

8. Yasukawa T, Kiba Y, Mizutani F. A Dual Electrochemical Sensor Based on a Test-strip Assay for the Quantitative Determination of Albumin and Creatinine. Anal Sci. 2015;31(7):583-9. <DOI>.

9. Soloviev V, Varnek A, Babain V, Polukeev V, Ashina J, Legin E, et al. QSPR modeling of potentiometric sensitivity towards heavy metal ions for polymeric membrane sensors. Sensors and Actuators B: Chemical. 2019 Dec;301:126941. <DOI $>$.

10. Mahanty B, Satpati AK, Kumar S, Leoncini A, Huskens J, Verboom W, et al. Development of polyvinyl chloride (PVC)-based highly efficient potentiometric sensors containing two benzenecentered tripodal diglycolamides as ionophores. Sensors and Actuators B: Chemical. 2020 Oct; 320:127961. <DOI>.

11. Bakker E, Bühlmann P, Pretsch E. Carrier-Based Ion-Selective Electrodes and Bulk Optodes. 1. General Characteristics. Chem Rev. 1997 Dec $1 ; 97(8): 3083-132$. <DOI $>$.

12. Pungor $E$, Tóth $K$. Ion selective electrodes. $A$ review. Anal Sci. 1987;3(5):387-93. <DOI>.

13. McQuade DT, Pullen AE, Swager TM. Conjugated Polymer-Based Chemical Sensors. Chem Rev. 2000 Jul $1 ; 100(7): 2537-74$. <DOI $>$.

14. Qi Z-L, Cheng $Y-H, X u ~ Z$, Chen M-L. Recent Advances in Porphyrin-Based Materials for Metal Ions Detection. IJMS. 2020 Aug 14;21(16):5839. $\leq \mathrm{DOI}>$.

15. Chen X, Wang $Y$, Zhao X, Liu B, Xu Y, Wang Y. A gadolinium(III)-porphyrin based coordination polymer for colorimetric and fluorometric dual mode determination of ferric ions. Microchim Acta. 2019 Feb;186(2):63. <DOI $>$.

16. Agir I, Yildirim R, Nigde M, Isildak I. Internet of Things Implementation of Nitrate and Ammonium Sensors for Online Water Monitoring. Anal Sci. 2021 Jul 10;37(7):971-6. <DOI>

17. Manov GG, Bates RG, Hamer WJ, Acree SF. Values of the Constants in the Debye-Hückel Equation for Activity Coefficients 1. J Am Chem Soc. 1943 Sep;65(9):1765-7. <DOI>.

18. Ozer T, Isildak I. A New Fe (III)-Selective Membrane Electrode Based on Fe (II) Phthalocyanine. J Electrochem Sci Technol. 2019 Sep 30; 321-8. <DOI $>$.

19. Li L, Zhang Y, Du P, Qian Y, Zhang P, Guo Q. Polymeric Membrane Electrodes Using Calix[4]pyrrole Bis/Tetra-Phosphonate Cavitands as Ionophores for Potentiometric Acetylcholine Sensing with High Selectivity. Anal Chem. 2020 Nov 3;92(21):14740-6. <DOI>. 
20. Mahajan RK, Sood P. Novel Copper (II)-selective electrode based on 2, 2': 5', 2'-terthiophene in PVC matrix. Int J Electrochem Sci. 2007;2:832-47.

21. Umezawa $Y$, Umezawa K, Sato H. Selectivity coefficients for ion-selective electrodes: Recommended methods for reporting $\mathrm{KA}$, Bpot values (Technical Report). Pure and Applied Chemistry. 1995 Jan 1;67(3):507-18. <DOI>.

22. K. Mittal S, Kumar S, Kaur N. Enhanced Performance of CNT-doped Imine Based Receptors as $\mathrm{Fe}(\mathrm{III})$ Sensor Using Potentiometry and Voltammetry. Electroanalysis. 2019 Jul;31(7):122937. $\leq \mathrm{DOI}>$.

23. Khan A, Khan AAP, Hussein MA, Neppolian B, Asiri AM. Preparation of new and novel wave like poly(2-anisidine) zirconium tungstate nanocomposite: Thermal, electrical and ion-selective studies. Chinese Journal of Chemical Engineering. 2019 Feb;27(2):459-66. <DOI.

24. Zareh $M M$, Zordek W, Abd-Alhady A. IronSelective Electrode Based on Phosphorylated Calix6-Arene Derivative. JST. 2014;04(04):186-94. <DOI>.

25. Yari A. A Novel Iron(III) Potentiometric Sensor Based on (E)-N'-((2- hydroxynaphthalen-3yl)methylene)benzohydrazide. Int J Electrochem Sci. 2016 Aug;6597-608. <DOI>.

26. Gupta VK, Singh AK, Al Khayat M, Gupta B.
Neutral carriers based polymeric membrane electrodes for selective determination of mercury (II). Analytica Chimica Acta. 2007 May;590(1):8190. $\leq \mathrm{DOI}>$.

27. Paut A, Prkić $A$, Mitar I, Bošković $P$, Jozić $D$, Jakić $M$, et al. Potentiometric Response of SolidState Sensors Based on Ferric Phosphate for Iron(III) Determination. Sensors. 2021 Feb 25;21(5):1612. <DOI $>$.

28. Wardak C, Lenik J. Application of ionic liquid to the construction of $\mathrm{Cu}(\mathrm{II})$ ion-selective electrode with solid contact. Sensors and Actuators B: Chemical. 2013 Dec;189:52-9. <DOI $>$.

29. Ali TA, Mohamed GG, El-Dessouky MMI, Abou El-Ella SM, Mohamed RTF. Modified Screen-Printed Electrode for Potentiometric Determination of Copper(II) in Water Samples. J Solution Chem. 2013 Jul;42(6):1336-54. <DOI>.

30. Jesús Gismera $M$, Antonia Mendiola $M$, Rodriguez Procopio J, Teresa Sevilla M. Copper potentiometric sensors based on copper complexes containing thiohydrazone and thiosemicarbazone ligands. Analytica Chimica Acta. 1999 Apr;385(13):143-9. $\leq \mathrm{DOI}>$.

31. Hassan S, Elnemma E, Mohamed A. Novel potentiometric copper (II) selective membrane sensors based on cyclic tetrapeptide derivatives as neutral ionophores. Talanta. 2005 May 15;66(4):1034-41. <DOI $>$. 
